\title{
A VISELKEDÉSVÁLTOZÁS SZINTJEI A TESTTÖMEG-MENEDZSELÉS FOLYAMATÁBAN - ÉLELMISZERFOGYASZTÁS ÉS FIZIKAI AKTIVITÁS
}

\author{
- भी०

\section{LEVELS OF BEHAVIOUR CHANGE IN THE COURSE OF BODY MASS MANAGEMENT - FOOD CONSUMPTION AND PHYSICAL ACTIVITY}

\author{
- 19 \\ Soós, Mihály \\ Kovács, Bence \\ SZAKÁLY, Zoltán

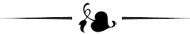 \\ Debreceni Egyetem, Gazdaságtudományi Kar, Marketing és Kereskedelem Intézet \\ (University of Debrecen, Faculty of Economics and Business, Institute of Marketing and Commerce) \\ H-4032 Debrecen, Böszörményi út. 138. \\ e-mail: soos.mihaly@econ.unideb.hu
}

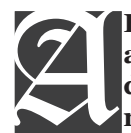

Based on the secondary data, it can be stated that more than half of the Hungarian population are obese, therefore, the actuality of this topic is approved. As a result of this research, the distribution of the examined sample has been executed by the phases of the Transtheoretical model. Thus, the situation in the precontemplation phase is better concerning the transfer to more regular physical activity (one-third of the sample) than the change for food consumption considered as healthier. Similar results were received in the phase of maintenance as well: onefourth of the sample answered that they did more regular physical activity with the minimal risk of fallback, and one-fifth of them thought that their healthier food consumption could be maintained. The fewest people are in the preparation phase of the transfer to healthier food nutrition, while in the case of more regular physical activity the rate is also lower in the phase of preparation compared to the contemplation, action and maintenance stages. A reason for that can be that the questioned see the change within one month, or they do not have the necessary determination to execute the change within such a short deadline, or to prepare themselves to the change. Considering the gender, in the first and last phases (precontemplation and maintenance) men are in greater proportion on both examined fields. In our opinion, the reason for it is that men are more determined considering their values and attitudes of their own body mass management. We think that the low number of people in the precontemplation phase is quite promising, especially in the case of more regular physical activity, since the people on the higher levels have the potential to develop healthier nutrition and physical activity, to enhance the motivation of contemplators, preparators and doers, and the support of maintainers can be a realistic step to reach the health political aims.

KulCSSZAVAK: Transzteoretikus Modell, testtömeg index (BMI), egészséges táplálkozás, rendszeres fizikai aktivitás, fenntartás

JEL-Kód (JEL CODE): Q13
KEYwORDs: Transtheoretical Model, body mass index, healthy nutrition, regular physical activity, maintenance 


\section{BEVEZETÉS - INTRODUCTION}

A fejlett társadalmak élelmiszerfogyasztását jellemző tápanyagbőség és a mozgásszegény életmód, valamint az egyének genetikai adottságainak együttes hatására a lakosság jelentős része túlsúlyossá vált. A lakosság testtömegének alakulása mára nem csupán egyénenkénti felelősség és érdek, hanem kiemelt szerepet játszik az állami költségvetést terhelő társadalombiztosítási költségek alakulásában is (TOLNAY és SZABÓ, 2004). A WHO (Egészségügyi Világszervezet) a fó mortalitási rizikófaktorok mérséklése miatt az élethosszig tartó fizikai aktivitást, mint az egészséget alapvetően meghatározó tényezőt tartja számon (CSÁNYI, 2010; WHO, 2008). Mindemellett a túlsúly és az elhízás esztétikai, köz- és önértékelési zavarokat is okozhat a lakosság körében, ezen akár az egyéni motivációk befolyásolásával is lehet változtatni (KOCSÁNDI, TOLNAY és SZABÓ, 2005).

A változtatásnak három alapvető módja közül (gyógyszeres kezelés, viselkedésterápia és mútéti beavatkozás) mi a viselkedésterápia részletesebb vizsgálatát választottuk. A lakosságra ható élelmiszerfogyasztással, tápanyag-összetétellel, testmozgással, életmóddal kapcsolatos és egyéb, a mindennapi életet érintő tudományosan megalapozott tanácsok hatására kialakult hazánkban a testtömeg-menedzselésüket tudatosan végzők csoportja. Számukra a népszerú divatdiéták alkalmazása helyett az élelmiszerek táplálkozási ajánlások szerinti rendszeres fogyasztása és a rendszeresebb fizikai aktivitás a fenntartható testtömeg-menedzselés alapja (CZEGLÉDI, 2012; SOÓS, 2014).

A közlemény témájaként választott testtömeg-menedzselés, egy olyan élethosszon át tartó folyamatként definiálható, amely az elfogyasztott élelmiszerek kiválasztását és a testmozgást foglalja magában az egészséges életmód kialakítása érdekében, oly módon, hogy az energiabevitel és az energia-felhasználás egyensúlyban legyen (SHARRON, 1997).

A téma elméleti hátterének megalapozásához ismernünk kell a fogyasztók testtömeg index szerinti csoportjait és azok arányát hazánkban, valamint a viselkedésváltozással kapcsolatos elméleti kutatási modellek közül a közlemény eredményeinek megszerzéséhez is felhasznált modellt.

\subsection{A BMI (testtömeg index) értelmezése és alakulása hazánkban - Interpretation and Progression of the $B M I$}

A BMI (testtömeg index) szerint a következő kategóriákba rendezhetôk a fogyasztók: a férfiak esetében 20,1-25,0, míg a nők esetében $18,7-23,8 \mathrm{~kg} / \mathrm{m}^{2}$ érték az ideális testtömeg/négyzetméter intervalluma, ha pedig egy pontos értéket szeretnénk meghatározni, azt mondhatjuk, hogy az ideális BMI értéke a férfiaknál 22,0, a nőknél 20,8 kg/m². Az intervallum alatt elhelyezkedő értékeket alacsony, míg az ideális intervallum felső értéke feletti BMI eredményeket túlsúly kategóriának nevezik. Túlsúly esetén a $30,0 \mathrm{~kg} / \mathrm{m}^{2}$ BMI értékig elhízásnak, 30,1-40,o kg/m² BMI érték között kóros elhízásnak, 40,1-50,0 kg/m² BMI értékig pedig extrém elhízásnak nevezik. A BMI értékek eltérő mértékűek a kor tekintetében. Más határértékkel szerepel az ideális BMI egy gyermek és egy felnőtt esetében (RODLER, 2008; CSÁNYI, 2010).

A hazai felnőtt lakosság 44,77\%-a tartozik az ajánlott értékủ BMI-vel rendelkezők csoportjába, 1,96\%-a sovány, 53,24\%-a túlsúlyos, ebből 17,73\% elhízott. A BMI hátránya, hogy a testalkati és testösszetételi jellemzóket figyelmen kívül hagyja, ideális testtömeg feletti értéke nem minden esetben jelez magas testzsír arányt, a túlsúly eredhet például megnövekedett izomtömegből, nagyarányú csonttömegből is, ezért önmagában jellemzően nem elegendő a tápláltsági állapot becslésére (RODLER, 2008; CSÁNYI, 2010).

\subsection{Az egészségmagatartást vizsgáló modellek - Models of Health Behavior}

Az egészségmagatartást vizsgáló modellek között szerepel például PENDER (1987) Egészségtámogató modellje, az Egészséghit Modell és a Védelem Motivációs Teória, amelyek szerint a fogyasztóknak inspirálásra, utasításra van szükségük a magatartásuk megváltozta- 
tásához és az egészségre vonatkozó döntéseik meghozatalához. Az Indokolt Cselekvés Teória és a Tervezett Viselkedés Teória azon alapszik, hogy a viselkedés előidézője nem más, mint a viselkedési szándék. Ebbe a kategóriába tartozik a Logikus cselekvések elmélete (AJZEN és FISHBEIN, 1980; RÁCZ, 2012) és a Tervezett magatartás elmélete (AJZEN, 1988) mellett a Viselkedésváltozás Transzteoretikus Modellje (TTM) (1. ábra) is, amely a közlemény primer kutatásában is alkalmazásra került, így a közleményben ezzel foglalkozunk részletesebben.

A PROCHASKA és DICLEMENTE (1984) szerzőpáros által alkotott Transzteoretikus Modellben az új, fenntartható egészség-magatartásra való áttérés öt lépcsőn (bezárkózás, szemlélődés, felkészülés, cselekvés és fenntartás) keresztül valósul meg (SZAKÁLY, 2011).

A bezárkózás szakaszában lévőknél az új magatartás kialakulása meglehetősen korlátozott, mivel az ide tartozók teljesen érdektelenek az egészségkampányok iránt és nincsenek tudatában az inaktivitásuk következményeivel sem. A második szakaszban (szemlélődés) a változtatás szükségességének tudatában van az egyén, viszont a rendelkezésre álló információk alapján mérlegeli a változtatás előnyeit és azok költségeit. Ha ezek a költségek túlzó mértéküek, akkor az adott személy nem jut el a harmadik szintre. A felkészüléskor az egyén már nemcsak tisztában van cselekedetei szükségességével, hanem megtervezett cselekvési tervvel is rendelkezik. Igénybe veszi a szakemberek, valamint orvosa tudását és tanácsait, de más autentikusnak vélt forrásból tájékozódva autodidakta magatartást is folytat. A cselekvés szakaszban már gyakorlati lépést is tesz az egyén. A szakemberek között az a megállapodás született, hogy az előző szokásoktól radikálisan eltérő magatartás minősül csupán valódi változásnak. Az utolsó lépcső, a fenntartás szakasza. Az egyén nem tart a visszaeséstől, az előzó lépésekben történt változtatások több, mint fél éve tartanak, mindennapossá és természetessé váltak számára, emellett nincs szükség a környezete felőli folyamatos megerősítésekre sem (SZAKÁLY, 2011).

A modell szakaszai esetében különböző marketingkommunikációs irányok ajánlottak. A bezárkózás szakaszában lévők számára a tájékoztatás és a felelősségtudat kialakítása, míg a szemlélődés szakaszában lévők esetében a különböző információszerzési források ajánlása, szaktanácsadás, programok ajánlása a célszerü. A felkészülési szakaszban az egyének támogatására, megerôsítésére irányuló kommunikációs üzenetek kialakítása ajánlott, viszont a cselekvési szakaszban az inspirálás, kitartás, pozitív visszacsatolás számít megfelelőnek. A fenntartás szakaszában lévő fogyasztók megcélzásának kommunikációjában kiemelt szerepet kap az egészségtudat, a lelkesedés további fenntartása, valamint az is, hogy az előző szakaszokban lévők számára egyfajta mintaként is szolgálnak, vagyis példamutató a tevékenységük.

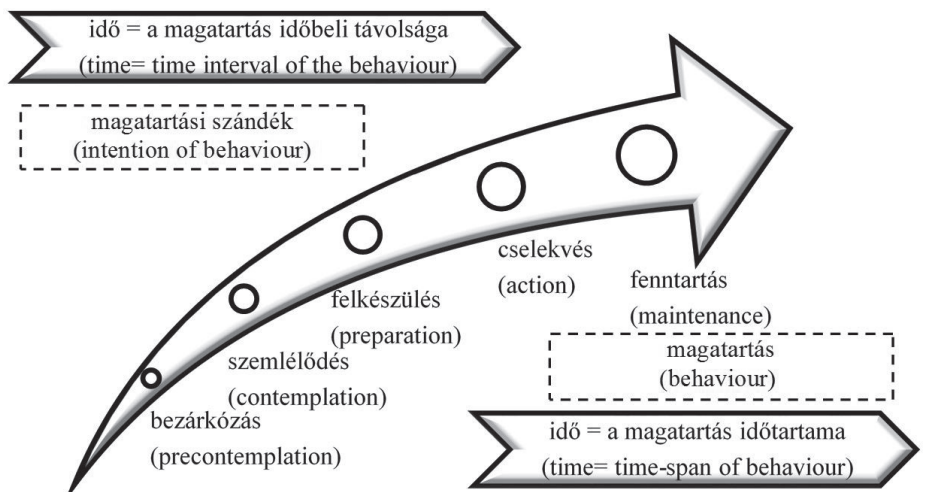

1. ÁBRA

A Viselkedésváltozás Transzteoretikus Modellje (TTM)

FIG. 1

(Transtheoretic Model of Behaviour Change (TTM))

Forrás (Source): Saját szerkesztés 2013 (Own construction) (VELICER et al. 1998, idézi SZAKÁLY, 2011) 


\section{ANYAg És Módszer -}

\section{MATERIAL AND METHOD}

A kutatás során szekunder és primer információgyưjtést egyaránt végeztünk. A választott téma áttekintése és a kutatás megalapozása a szekunder információk összegyưjtésével kezdődött, amelynek során a hazai és külföldi szakirodalmak segítségével komplex képet kaptunk a témával kapcsolatos előzetes kutatások eredményeirôl és a tudomány jelenlegi állásfoglalásairól.

A primer (kvantitatív) kutatás keretében, egy 500 fős kérdőíves megkérdezést hajtottunk végre. A kutatás során 658 kitöltött kérdőívből az adattisztítás és a nem szerinti reprezentativitás kialakítása után 500-at tartottunk meg. A mintában a férfiak $48,2 \%$, a nók $51,8 \%$ arányban jelennek meg, viszont felülreprezentáltak a fiatal felnőttek (18-25 évesek), valamint az érettségizettek és a diplomával rendelkezők.

A megkérdezés online kérdőív formájában történt, a kérdőív elérhetőségét tartalmazó linket elektronikus felületen juttattuk el a megkérdezettekhez, akik továbbították azt a saját címlistájukban szereplők felé. A kérdőív háttérváltozói között szerepelt a nem, a kor, az iskolai végzettség, a szubjektív jövedelemérzet, a testtömeg és a testmagasság. A kvantitatív kutatások eredményeit az SPSS 23.0 matematikai-statisztikai elemző szoftvercsomag segítségével értékeltük ki. Az adatok rögzítése során metrikus és nem metrikus mérési skálákat egyaránt alkalmaztunk. A kérdőíves megkérdezés során kapott válaszokat leíró statisztikai mutatókkal értékeltük, valamint gyakorisági mutatókat és kereszttáblás elemzéseket hajtottunk végre (MURRAY, 1995; MOLNÁR, 2007; SAJTOS és MITEV, 2007). Ahhoz, hogy a vizsgált változók közötti szignifikáns kapcsolatot bizonyítsuk (vagy elvessük) a Pearson-féle $\mathrm{Chi}^{2}$ próbát alkalmaztuk, az eredmények értelmezését $\mathrm{p}<0,05$ szint alatt végeztük.

A magyar lakosság által egészségesebbnek vélt élelmiszerfogyasztásra történő áttérés vizsgálatára a Magatartásváltoztatási mutató számítását alkalmaztuk. Ezen módszer alkalmazásával az 1. ábrán bemutatott Transzteoretikus Modell (PROCHASKA és DICLEMENTE, 1984) szakaszaihoz tartozó százalékos értékeket szoroztuk meg a következők szerint. A „bezárkózók” esetében 1-gyel, a „szemlélődőknél” 2-vel, a „felkészülőknél” 3-mal, a „cselekvőknél” 4-gyel és a „fenntartók” esetében 5-tel szoroztuk a hozzájuk tartozó százalékos értékeket, majd a kapott eredményeket összeadtuk és elosztottuk 100-zal, így a skála öt százalékos értéke egy számmal volt kifejezhető. Az 5-ös érték fejezi ki azt, hogy a minta kizárólag fenntartókból áll (magas a változtatás hajlandósága), az 1-es érték pedig azt jelenti, hogy a minta kizárólag bezárkózókból áll (alacsony a változtatás hajlandósága).

\section{EREDMÉNYEK - RESUltS}

\subsection{Az egészségesebbnek vélt táplálkozásra történő áttérés alakulása - Switch to a Nutrition Considered as Healthier}

Elsőként az élelmiszer-fogyasztói magatartás változását az egyén által egészségesebbnek vélt táplálkozásra történő áttérésen keresztül mutatjuk be (1. táblázat). A táblázat állításai a következő öt szakaszt jelentik: bezárkózás, szemlélődés, felkészülés, cselekvés és fenntartás.

Bezárkózás: Az egészséges táplálkozásra történő áttérést nem tervezők 21,6\%-os arányt képviselnek. A változtatást elutasítók közé tartozik a férfi válaszadók 27,0\%-a és a nők 16,6\%-a, tehát a férfiak tekinthetők paszszívabbnak e területen $(\mathrm{p}<0,01)$ (1. táblázat). A bezárkózás az idősebb korcsoport tagjaira jellemző legnagyobb mértékben. A 60 évesnél idősebbek 35,7\%-a nem tervez elmozdulást egy egészségesebbnek vélt táplálkozás irányába. Legkevésbé $(12,5 \%)$ a 40-49 éves korcsoporton belül tapasztalható a bezárkózás $(\mathrm{p}<0,05)$. Az alacsony BMI-vel rendelkező férfiak 35,0\%-a nem tervez változtatni a következő fél év során élelmiszerfogyasztási szokásain $(\mathrm{p}<0,01)$. Ezzel az aránnyal a férfiak körében ez a csoport minősül a leginkább elutasítónak. A nők körében, a férfiakhoz hasonlóan, az alacsony BMI-vel rendelkezők a legbezárkózottabbak (25,0\%). A legkevésbé passzívak mindkét nemnél (férfi: 16,5\%; nő: 2,8\%) a túlsúlyosak ( $\mathrm{p}<0,001)$. A jövedelem háttérváltozó szerint is szignifikáns a kapcsolat a bezárkózás vonatkozásában. Ebben a szakaszban van a rendszeres 
napi megélhetési gondokkal küzdők 80\%-a. Ez az érték bizonyítja, hogy az egészségesebbnek vélt táplálkozás a fogyasztók prekoncepciója szerint nagyobb anyagi teherrel is jár, amelyet a szerényebb jövedelmúek nem képesek megfizetni. Azoknak a válaszadóknak, akik a havi jövedelmükből megélnek, és ebből keveset félre is tudnak tenni, a 24,0\%-a, azoknak pedig, akik megélnek belőle, de félre már nem tudnak tenni, a 23,2\%-a semminemü változtatást nem tervez az általa egészségesebbnek vélt táplálkozást tekintve $(\mathrm{p}<0,01)$.

Szemlélődés: A válaszadók 22,6\%-a érez erős késztetést arra, hogy áttérjen egy általa egészségesebbnek vélt táplálkozásra. Elsősorban a 40-49 (37,5\%) és az 50-59 éves $(47,1 \%)$ korcsoportra jellemző ez a magatartás ( $<<0,01)$. A szemlélődés legnagyobb arányban (29,6\%) „az éppen arra elég, hogy megéljen a jövedelméből, de félretenni már nem tud" kategóriába tartozókra jellemző. Hasonló mértékben $(26,9 \%)$ vannak jelen a csoporton belül azok, akiknek jövedelme néha arra sem elég, hogy megéljenek belőle ( $\mathrm{p}<0,01)$. A túlsúlyos férfiakra (28,9\%) és a túlsúlyos nőkre (27,8\%) jellemző leginkább ez a hezitáló magatartás. A férfiaknál az ideális BMI-vel rendelkezőkre (13,4\%), míg a nőknél az alacsony testtömeg-indexűekre jellemző legkevésbé a szemlélődés $(\mathrm{p}<0,001)$.

Felkészülés: A megkérdezettek mindössze 17,2\%-a sorolható a felkészülés szakaszába. A férfiak 13,7, a nők 20,5\%-a tervezi, hogy a következő fél évben áttér egy általa egészségesebbnek vélt táplálkozásra $(\mathrm{p}<0,01)$. Meglepő eredmény, hogy az átlagosnál alacsonyabb jövedelmúek 23,1\%-a azonosítható a felkészülés szakaszában, és a jövedelem növekedésével csökken azok aránya, akik a következő hat hónapban változtatni szeretnének táplálkozásukon. Leginkább az elhízott nőkre (30,6\%) jellemző a táplálkozás megváltoztatásának tervezése $(\mathrm{p}<0,01)$.
Cselekvés: A válaszadók 18,6\%-a - közülük is többségben a nők $(22,4 \%)$ - tértek át az elmúlt fél év során egy általuk egészségesebbnek vélt táplálkozásra. A cselekvési szakaszba a fiatal felnőttek (18-29 évesek) 23,2\%-a tartozik, a náluk idősebb korcsoportok aránya a 15\%-ot sem éri el, 60 év felettiek pedig egyáltalán nincsenek jelen ebben a csoportban $(\mathrm{p}<0,01)$.

A szakaszban 26,9\% azok aránya, akiknek jövedelme néha arra sem elég, hogy megéljenek belőle. A többi jövedelemkategóriába tartozó válaszadói arány nem éri el a 20\%-ot. A felkészülőkhöz hasonlóan, a cselekvő szakaszban is magasabb arányban vannak jelen a túlsúlyos nők (27,8\%), mint a többi BMI kategóriába tartozó válaszadók ( $\mathrm{p}<\mathrm{0}, \mathrm{o1})$.

Fenntartás: Az eredmények alapján a megkérdezettek 20,0\%-a már több mint hat hónapja képes fenntartani az általa egészségesebbnek vélt táplálkozását. A nők kisebb aránya $(17,8 \%)$ valószínüleg a kampányszerüen végzett fogyókúrás módszerek alkalmazásával magyarázható, így számukra nincs egyetlen jól bevált táplálkozási módszer. A fenntartás inkább a fiatalabb korcsoportokra jellemző, míg az idősebbekre kevésbé ( $\mathrm{p}<0,05)$. A 20-29 évesek 24,4\%-a, míg a 30-39 évesek 21,9\%-a tartja fenn több, mint fél éve az általa egészségesebbnek vélt táplálkozását. A fenntartási szakasz a jelentősen az átlag feletti jövedelműek 31,4\%-ára ( $\mathrm{p}<0,05)$, míg az ideális BMI-vel rendelkező férfiak 25,6\%-ára jellemző leginkább ( $\mathrm{p}<0,01)$.

A magatartásváltozási mutató értéke 2,928, amely közepes változtatási hajlandóságot jelez, eszerint a megkérdezettek jellemzően a felkészülési szakaszban vannak. A nemek tekintetében vizsgálva a kérdést, kismértékű eltérést tapasztalunk. A nők esetében magasabb a magatartásváltozási mutató értéke (3,023), mint a férfiaknál $(2,829)$, eszerint az egészségesebbnek vélt élelmiszerfogyasztásra történő áttérésben a nők előrébb járnak a férfiaknál. 
Az egészségesebbnek vélt táplálkozásra történó áttérés alakulása, $\mathrm{N}=500$

(Switch to a Nutrition Considered as Healthier, $N=500$ )

\begin{tabular}{|c|c|c|c|}
\hline \multirow{2}{*}{$\begin{array}{l}\text { A viselkedésváltozás szakaszai } \\
\text { (Phases of Behaviour Change) }\end{array}$} & \multicolumn{3}{|c|}{$\begin{array}{c}\text { Válaszok megoszlása, \% } \\
\text { (Answers, \%) }\end{array}$} \\
\hline & $\begin{array}{l}\text { Férfi } \\
\text { (Male) }\end{array}$ & $\begin{array}{c}\text { Nő } \\
\text { (Female) }\end{array}$ & $\begin{array}{c}\text { Összesen } \\
\text { (Total) }\end{array}$ \\
\hline $\begin{array}{l}\text { BEZÁRKÓZÁS - A következő hat hónapban nem szándékozom } \\
\text { áttérni egy általam egészségesebbnek vélt táplálkozásra. } \\
\text { (PRECONTEPLATION - I don't want to change my nutrition } \\
\text { to a healthier one in the next six months.) }\end{array}$ & 27,0 & 16,6 & 21,6 \\
\hline $\begin{array}{l}\text { SZEMLÉLÓDÉS - Erős késztetést érzek arra, hogy áttérjek egy } \\
\text { általam egészségesebbnek vélt táplálkozásra. } \\
\text { (CONTEMPLATION - I feel a strong urge to switch to a } \\
\text { nutrition considered as healthier.) }\end{array}$ & 22,4 & 22,8 & 22,6 \\
\hline $\begin{array}{l}\text { FELKÉSZÜLÉS - A következő egy hónapban lépéseket fogok } \\
\text { tenni, hogy áttérjek egy általam egészségesebbnek vélt táplál- } \\
\text { kozásra. } \\
\text { (PREPARATION - I am going to take steps to switch to a } \\
\text { healthier nutrition in the next month.) }\end{array}$ & 13,7 & 20,5 & 17,2 \\
\hline $\begin{array}{l}\text { CSELEKVÉS - Az elmúlt hat hónap során áttértem egy általam } \\
\text { egészségesebbnek vélt táplálkozásra. } \\
\text { (ACTION - In the last } 6 \text { months I have switched to a healthier } \\
\text { nutrition.) }\end{array}$ & 14,5 & 22,4 & 18,6 \\
\hline $\begin{array}{l}\text { FENNTARTÁS - Már több mint hat hónapja egészségesebben } \\
\text { táplálkozom, a visszaesés esélye régi táplálkozási szokásaimra } \\
\text { minimális. } \\
\text { (MAINTENANCE - For more than } 6 \text { months I have been } \\
\text { eating more healthily, the chance of fallback to the previous } \\
\text { nutrition habits is minimal.) }\end{array}$ & 22,4 & 17,8 & 20,0 \\
\hline Magatartásváltozási mutató (Index of behaviour change) & 2,829 & 3,023 & 2,928 \\
\hline
\end{tabular}

Forrás (Source): Saját kutatás (Own construction)

\subsection{A rendszeresebbnek vélt fizikai aktivitásra történő áttérés alakulása - Switch to a More Regular Physical Activity}

Második lépésben a rendszeresebbnek vélt fizikai aktivitásra történő áttérés vizsgálatára koncentráltunk. Ebben az esetben is a Transzteoretikus Modell szakaszain keresztül mutatjuk be a vizsgált minta megoszlását. Az eredményeket a 2. táblázat tartalmazza.

Bezárkózás: A táblázat jól szemlélteti, hogy a válaszadóknak mindössze 8,0\%-a zárkózik el a rendszeresebbnek vélt fizikai aktivitásra történő áttéréstől. Ez az érték az egészségesebbnek vélt élelmiszerfogyasztástól való elzárkózás értékének egyharmada, tehát a fizikai aktivi- tás terén nyitottabbak a válaszadók. Nagyobb arányban (11,2\%) a férfiak zárkóznak el a rendszeresebbnek vélt fizikai aktivitástól, a nőknek csupán 5,0\%-a nyilatkozott úgy, hogy nem tervez semmilyen változtatást ( $\mathrm{p}<0,01)$ (2. táblázat). A bezárkózók között legnagyobb arányban $(14,3 \%)$ a 60 évesnél idősebbek jelennek meg ( $\mathrm{p}<\mathrm{0}, 01)$, míg lényegesen kisebb arányban a fiatalabb korosztályok (18-29 éves korcsoport 5,9\%; a 30-39 és a 40-49 éves korcsoportok $5,9 \%$ és 6,2\%). Családi állapot szerint az özvegyek $66,7 \%$-a nem tervez semmilyen fizikai aktivitást, mellettük az élettárssal élők szerepelnek még nagyobb arányban $(\mathrm{p}<\mathrm{0}, \mathrm{o01})$. Legkevésbé elutasítóak ezen a téren a nőtlenek és hajadonok $(6,4 \%)$. 
Szemlélődés: A válaszadók 24,2\%-a, köztük a nők 28,6, illetve a férfiak 19,5\%-a érez erős késztetést arra, hogy áttérjen egy általa rendszeresebbnek vélt fizikai aktivitásra $(\mathrm{p}<0,01)$. Az 50-59 éves (47,1\%) és a 40-49 éves (40,6\%) korcsoportokon belül vannak nagyobb számban a mérlegelők ( $\mathrm{p}<0,05)$. Ebben a szakaszban a nőtlen/hajadon válaszadók aránya a legalacsonyabb (18,8\%; p<0,01). A munkanélküli és az aktív fizikai dolgozók 40,0\% feletti aránynyal jelennek meg a szemlélődők között, ám a további szakaszokba (Cselekvés és Fenntartás) jellemzően már nem lépnek tovább. Anyagi helyzetüket tekintve az átlagos jövedelműek (32,8\%) jelennek meg legnagyobb arányban, ebben a szakaszban. Megállapítható továbbá, hogy legnagyobb mértékben (30,6\%) a túlsúlyos nők éreznek késztetést arra, hogy áttérjenek a rendszeres fizikai aktivitásra $(\mathrm{p}<0,001)$.

Felkészülés: A megkérdezettek 20,0\%-a szándékozik lépéseket tenni az aktív testmozgásra történő áttérés terén. A férfiak 17,0, míg a nők 22,8\%-a tartozik ebbe a szakaszba ( $\mathrm{p}<0,01)$. Bár az eredmények alapján a felkészülés szakaszáig nagy arányban jutnak el a 60 év feletti válaszadók (35,7\%), a cselekvés és a fenntartás már nem jellemző rájuk. A 30-39 és a 40-49 éves korcsoportok a felkészülést követő szakaszokban egyre nagyobb arányban képviseltetik magukat, és közülük kerülnek ki azok is, akiknek mindennapi életük részévé vált a rendszeres fizikai aktivitás ( $\mathrm{p}<0,001)$. Kiemelkedően magas arányban (25,0\%) vannak jelen a nőtlen/hajadon családi állapotú válaszadók a felkészülők között. Mind a nők (27,8\%), mind pedig a férfiak $(28,9 \%)$ között a túlsúlyos válaszadók aránya a nagyobb $(\mathrm{p}<0,01)$.

Cselekvés: A válaszadók 22,0\%-a nyilatkozott úgy, hogy az elmúlt hat hónap során áttért a rendszeresebben végzett fizikai aktivitásra. A nők 25,1, míg a férfiak 19,1\%-a jutott el ebbe a szakaszba (p<0,01). A 18-29 évesek 23,5\%-a, míg a 30-39 évesek 23,0\%-a tartozik a cselekvők csoportjába $(\mathrm{p}<0,05)$. Az elváltak fele, a házastársuktól külön élők egyharmada (33,3\%) végez rendszeresen fizikai aktivitást $(\mathrm{p}<0,05)$. Elmondható továbbá, hogy az átlagos $(24,8 \%)$, valamint a jelentősen az átlag feletti jövedelemmel rendelkező (24,3\%) válaszadók aránya a meghatározó ebben a szakaszban $(\mathrm{p}<\mathrm{0}, 01)$. A testtömeg index alapján történő vizsgálatok szerint az elhízott férfiak (25,0\%) és a túlsúlyos nők (27,8\%) között jellemző leginkább a rendszeres testmozgás végzése $(\mathrm{p}<0,01)$.

Fenntartás: A válaszadók 25,6\%-a tartja fenn a testtömeg menedzselése során kialakított rendszeres testmozgását több mint fél év után is. A férfiak nagyobb arányban (33,2\%) jelennek meg a fenntartók között, mint a nők $(18,5 \% ; \mathrm{p}<0,01)$. A $18-29(57,8 \%)$ és a $30-39$ évesek (30,5\%) között jellemző magas arányban a rendszeres fizikai aktivitás végzése ( $<<0,05)$. Családi állapot szerint a házastársuktól külön élőkre (33,3\%) és a nőtlenekre/ hajadonokra (26,1\%) jellemző legnagyobb arányban a rendszeres testmozgás hosszú távú fenntartása $(\mathrm{p}<0,01)$. A férfiak között az alacsony (40,1\%) és az ideális BMI-vel rendelkezők (39,0\%) azok, akik társaikhoz képest nagyobb arányban sorolhatók a fenntartók közé $(\mathrm{p}<0,001)$.

A magatartásváltozási mutatót vizsgálva megállapítható, hogy a rendszeresebbnek vélt fizikai aktivitásra történő áttérés értéke magasabb (3,332), mint az egészségesebbnek vélt élelmiszerfogyasztás esetében realizált. Ez alapján megállapítható, hogy ha csekély mértékben is, de a fizikai aktivitás megváltoztatására nyitottabban a válaszadók, mint a jelenlegi étrendjük módosítására. A nemek tekintetében vizsgálva a kérdést, megállapítható, hogy a fizikai aktivitás területén a férfiaknál magasabb a magatartásváltozási mutató értéke $(3,436)$, mint a nóknél (3,235). Mindezek ismeretében arra lehet következtetni, hogy az egészségesebbnek vélt- élelmiszerfogyasztásra történó áttérést a nők, míg a rendszeresebb fizikai aktivitásra való áttérést a férfiak tervezik nagyobb mértékben. 
A rendszeresebbnek vélt fizikai aktivitásra történő áttérés alakulása, $\mathrm{N}=500$

(Switch to a More Regular Physical Activity, N=50o)

\begin{tabular}{|c|c|c|c|}
\hline \multirow{2}{*}{$\begin{array}{l}\text { A viselkedésváltozás szakaszai } \\
\text { (Phases of Behaviour Change) }\end{array}$} & \multicolumn{3}{|c|}{$\begin{array}{c}\text { Válaszok megoszlása, \% } \\
\text { (Answers, \%) }\end{array}$} \\
\hline & $\begin{array}{c}\text { Férfi } \\
\text { (Male) }\end{array}$ & $\begin{array}{c}\text { Nő } \\
\text { (Female) }\end{array}$ & $\begin{array}{c}\text { Összesen } \\
\text { (Total) }\end{array}$ \\
\hline $\begin{array}{l}\text { BEZÁRKÓZÁS - A következő hat hónapban nem szándékozom } \\
\text { áttérni egy általam rendszeresebbnek vélt fizikai aktivitásra. } \\
\text { (PRECONTEPLATION - I don’t want to change to a more } \\
\text { regular physical activity in the next six months.) }\end{array}$ & 11,2 & 5,0 & 8,0 \\
\hline $\begin{array}{l}\text { SZEMLÉLÓDÉS - Erős késztetést érzek arra, hogy áttérjek egy } \\
\text { általam rendszeresebbnek vélt fizikai aktivitásra. } \\
\text { (CONTEMPLATION - I feel a strong urge to switch to a more } \\
\text { regular physical activity.) }\end{array}$ & 19,5 & 28,6 & 24,2 \\
\hline $\begin{array}{l}\text { FELKÉSZÜLÉS - A következő egy hónapban lépéseket fogok } \\
\text { tenni, hogy áttérjek általam rendszeresebbnek vélt fizikai } \\
\text { aktivitásra. } \\
\text { (PREPARATION - I am going to take steps to switch to a } \\
\text { more regular physical activity in the next month.) }\end{array}$ & 17,0 & 22,8 & 20,0 \\
\hline $\begin{array}{l}\text { CSELEKVÉS - Az elmúlt hat hónap során áttértem egy általam } \\
\text { rendszeresebbnek vélt fizikai aktivitásra. } \\
\text { (ACTION - In the last } 6 \text { months I have switched to a more } \\
\text { regular physical activity.) }\end{array}$ & 19,1 & 25,1 & 22,2 \\
\hline $\begin{array}{l}\text { FENNTARTÁS - Már több mint hat hónapja egészségesebben } \\
\text { táplálkozom, a visszaesés esélye régi fizikai aktivitási } \\
\text { szokásaimra minimális. } \\
\text { (MAINTANCE - For more than } 6 \text { months I have been eating } \\
\text { more healthily, the chance of fallback to the previous physical } \\
\text { activity habits is minimal.) }\end{array}$ & 33,2 & 18,5 & 25,6 \\
\hline Magatartásváltozási mutató (Index of behaviour change) & 3,436 & 3,235 & 3,332 \\
\hline
\end{tabular}

Forrás (Source): Saját kutatás (Own construction)

\section{KöVETKEZTETÉSEK ÉS}

\section{JAVASLATOK - CONCLUSIONS AND SugGESTIONS}

A szekunder adatok alapján megállapítható, hogy a hazai lakosság több mint fele elhízott, ezáltal a vizsgált téma aktualitása beigazolódott. Eredményként megállapításra került a vizsgált minta megoszlása a Transzteoretikus modell szakaszai alapján. Így a rendszeresebbnek vélt fizikai aktivitásra történő áttérés esetén a bezárkózás szakaszában jobb a helyzet, mint az egészségesebbnek vélt élelmiszerfogyasztásra való áttérésnél, a minta harmadannyi alanya tartozik az elóbbi szempontból a bezárkózó szakaszba. A fenntartás szakaszában is hasonló eredményeket kaptunk, a minta ne- gyedének rendszeresebb a vélt fizikai aktivitása a visszaesés minimális kockázatával, míg ötöde véli úgy, hogy fenntartható az egészségesebb élelmiszerfogyasztása.

A legkisebb arányban az egészségesebbnek vélt táplálkozásra történő áttérés felkészülés szakaszában vannak a fogyasztók, de ugyanez a tendencia érvényesül a fizikai aktivitás esetében is. Ennek oka talán az lehet, hogy a válaszadók a változástól való félelmüket egy egyhónapos határidő megfogalmazásával már nem tudják vagy nem akarják fokozni vagy nincs meg a kellő elszántságuk a változtatás ilyen rövid határidejű megvalósításához, esetleg a változásra való felkészülésükhöz. A nemek tekintetében a változás szélső szakaszaiban (bezárkózás és fenntartás) a férfiak vannak nagyobb arányban 
mindkét vizsgált területet tekintve. Ennek oka az lehet, hogy a férfiaknak nagyobb az eltökéltsége a testtömeg-menedzseléshez kapcsolódó értékek és attitűdök iránt, de egyúttal alacsony motivációs szint is jellemző rájuk.

A kutatás szerint jobb a helyzet a rendszeresebbnek vélt fizikai aktivitást tekintve, mint az egészségesebbnek vélt táplálkozás esetében. Ezt igazolják a szélsőséges (bezárkózás és fenntartás) szakaszok megoszlási viszonyszámai is. Úgy gondoljuk, hogy mindenképpen bíztató a bezárkózás viszonylag alacsony aránya, fóként a rendszeresebbnek vélt fizikai aktivitás terén. Ennek oka, hogy a változtatás magasabb szintjein lévőkben megvan a potenciál egy egészségesebbnek vélt táplálkozás és fizikai aktivitás kialakítására, továbbá a szemlélődők, a felkészülők és a cselekvők motivációjának fokozására.

A kutatást érdemesnek tartjuk megismételni 1-3 éves időtávon belül, hogy pontosabb adatokat nyerjünk a végbement változásokról az egyes szakaszok között. Prognózis készítése szempontjából is szükséges a kutatás jövőbeli megismétlése.

\section{5. ÖSSZEFOGLALÁS - SUMMARY}

A kutatás során a Viselkedésváltozás Transzteoretikus Modelljét alkalmaztuk. Ennek során lakossági kérdőíves megkérdezést hajtottunk végre az egészségesebbnek vélt élelmiszerfogyasztásra és a rendszeresebbnek vélt fizikai aktivitásra történő áttérés szakaszaira vonatkozóan.

$\mathrm{Az}$ eredmények alapján megállapítható, hogy hazánkban az élelmiszerfogyasztási szokások megváltoztatása nehezebb, mint fizikai aktivitásra ösztönözni az egyéneket. Ezt bizonyítja az is, hogy az egészségesebbnek vélt élelmiszerfogyasztásra történő áttérés esetében a bezárkózók a megkérdezettek 21,6\%-át teszik ki, addig a rendszeresebbnek vélt fizikai aktivitás esetében ez az arány csupán 8,0\%. A változtatásoktól mindkét vizsgált esetben a férfiak zárkóznak el nagyobb arányban, viszont a fenntartás szakaszában szintén a férfiak vannak többségben. A szemlélődés, a felkészülés, valamint a cselekvés szakaszokban jellemzően a nők dominálnak, viszont ezek a szakaszok inkább az információszerzésről, a tevékenység megkezdésének előkészületeiről, illetve rövid távú, esetenként kampányszerü alkalmazásokról szólnak. Ezt az eredményt erősítik a magatartásváltozási mutatók értékei is. A fenntartás szakaszában a már minimum fél éve új szokásokra áttért fogyasztók szerepelnek és köztük a nők nagyon alacsony arányban képviseltetik magukat a férfiakkal szemben.

\section{IRODALOMJEGYZÉK - REFERENCES}

Ajzen, I. - Fishbein, M.: Understanding Attitudes and Predicting Social Behaviour. Englewood Cliffs. NJ, Prentice Hall, 1980.

Ajzen, I.: Attitudes, Personality and Behaviour. Milton Keynes, Open UP, 1988.

Czeglédi E.: A viselkedésváltozás transzteoretikus modelljének alkalmazási lehetőségei az elhízás kezelésében. Mentálhigiéné és Pszichoszomatika. 2012. 13 (4) 411-434.

Csányi T.: A fizikai aktivitás és egészség fiatal korban. Egészségfejlesztés. 2010. 51 (1-2) 43-48.

Kocsándi A. - Tolnay P. - Szabó S. A.: A korszerü diéta - kiegyensúlyozott táplálkozásés mozgás. Testtömegoptimálás a 21. században. Élelmezési Ipar. 2005. 59 (6-7) 184-186.

Molnár T.: Egyszerúen statisztika. Perfekt Kiadó, Budapest, 2007.

Murray, R. S.: Statisztika elmélet és gyakorlat. Panem Kiadó, Budapest, 1995.

Pender, N. F.: Health Promotion in Nursing Practice. Appleton \& Lange, 1987.

Prochaska, J. O. - DiClemente, C. C.: The Transteoretical Approach: Crossing Traditional Boundaries of Change. Dorsey Press, Homewood III., 1984.

Rácz G.: Az értékek változásának és a fenntartható fejlődés trendjének hatása a hazai élelmiszerfogyasztásra. Doktori értekezés. Gödöllő, 2012.

Rodler I.: Élelmezés- és táplálkozásegészségtan. Medicina Könyvkiadó, Budapest, 2008.

Sajtos L. - Mitev A.: SPSS kutatási és adatelemzési kézikönyv. Alinea Kiadó, Budapest, 2007. 
Sharron, D.: Overweight and Weight Management: The Health Professional's Guide to Understanding and Treatment. Aspen Publishers Inc., Maryland, 1997.

Soós M.: Azélelmiszer-fogyasztói magatartás és a testtömeg-menedzselés összefüggései. Doktori értekezés. Kaposvár, 2014.

Szakály Z:: Táplálkozásmarketing. Mezőgazda Kiadó, Budapest, 2011.

Tolnay P. - Szabó S. A.: Testtömegoptimálás, a sikeres fogyókúra ismérvei. Élelmezési Ipar. 2004. 58 (2) 60-61.
Velicer, W. F. - Prochaska, J. O. - Fava, J. L. - Norman, G. J. Redding, C. A.: Smoking Cessation and Stress Management: Application of the Transtheoretical Model of Behaviour Change. Homeostasis. 1998. 38 (5-6) 216233.

World Health Organization (WHO): Action Plan for the Global Strategy for the Prevetion and Control of Noncommunicable Diseases. Geneva, 2008.

\section{JEGYZETEK $*$ NOTES}

